Животные в условиях интенсивных технологий

\title{
ГИСТОСТРУКТУРА ТРАХЕАЛЬНОЙ СТЕНКИ У ЦЫПЛЯТ-БРОЙЛЕРОВ В ЗАВИСИМОСТИ ОТ УСЛОВИЙ ЦИРКУЛЯЦИИ ВОЗДУХА В ЗАКРЫТЫХ ПОМЕЩЕНИЯХ
}

\author{
В.И. ФИСИНИН ${ }^{1}$, И.П. САЛЕЕВА ${ }^{1}$, А.К. ОСМАНЯН ${ }^{2}$, В.П. ПАНОВ ${ }^{2}$,

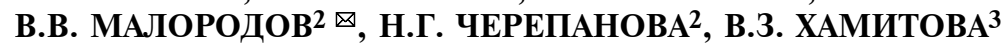

В настоящее время наблюдается интенсификация производства мяса бройлеров, в связи с чем увеличивается число исследований, посвященных оптимизации и приведению к нормативам микроклимата в помещениях для выращивания птицы. При этом уделяется недостаточно внимания воздействию параметров микроклиимата на дыхательный аппарат птиц. В представленной работе впервые показано, что циркуляция воздуха в закрытых помещениях способствует поддержанию продуктивности, улучшению гистологической структуры и гистохимического статуса трахеальной стенки у цыплят-бройлеров. Цель эксперимента - определение гистологической и гистохимической структуры трахеальной стенки у цыплят-бройлеров (Gallus gallus domesticus) кросca Ross 308, которые содержались в вентилируемых помещениях или при отсутствии циркуляции воздуха. Исследование было выполнено в 2020-2021 годах на птицефабрике ООО «Челны-Бройлер» (Республика Татарстан). Цыплят-бройлеров кросса Ross 308 выращивали до 39-суточного возраста в пяти закрытых производственных корпусах, которые различались по равномерности распределения воздушных потоков и циркуляции воздуха (пять групп по 35 гол. в каждой). При морфометрических исследованиях использовали 175 образцов трахей бройлеров всех групп (средняя живая масса 2500 г). Обзорные препараты (по три среза для каждого образца, всего 525 препаратов) получали окрашиванием гематоксилином и эозином. Для гистохимических исследований кислых и нейтральных муцинов срезы окрашивали комбинированным методом выявления полисахаридов с применением реакции Шифф-йодной кислоты (ШИК-реакции) и альцианового синего по методикам, рекомендованным «ООО Лабико» (Россия). В помещениях, где содержались II, III и IV контрольные группы, отсутствовала циркуляция воздуха, в залах выращивания птиц из I и V опытных групा были установлены циркуляционные осевые вентиляторы SF-550-02 («AgroKurs», Россия; производительность 8,5 тыс. м³/ч). Циркуляционные вентиляторы запускали с 10-суточного возраста бройлеров. Недостаточность циркуляции воздушных потоков в залах выращивания птиц вызывала деструктивные изменения слизистой оболочки трахеи, которые выражались в разрастании собственной пластинки слизистой, отеке, уменышении высоты эпителия, разрушении ресничек. Это приводило к метаплазии эпителия и нарушению мукоцилиарного транспорта. Так, у птицы в I опытной группе толщина слизистой оболочки и входящей в ее состав собственной пластинки оказалась минимальной - соответственно $147,2 \pm 3,3$ и 129,1 $\pm 3,1$ мкм, в III контрольной группе эти показатели были максимальными $-404,7 \pm 9,4$ мкм и $395,7 \pm 9,4$ мкм (p $\leq 0,01)$. Толщина эпителиального слоя трахеи была достоверно выше в I и V опытных группах (в среднем на 14\%) в сравнении со II, III и IV контрольными группами (p $\leq 0,01)$. Отсутствие циркуляции воздуха в помещениях привело к достоверному снижению высоты ресничек во II, III и IV группах соответственно на 39,5; 58,1 и 67,5 \% по отношению к I и V группам (p $\leq 0,01)$. Прирост живой массы птицы в 5-недельном возрасте в I опытной группе был выше в сравнении со II, III и IV контрольными группами соответственно на 6,$5 ; 3,2$ и $7,1 \%$ (p $\leq \mathbf{0 , 0 5})$. Полученные гистологические препараты позволяют предположить наличие у птиц в пласте эпителия трахеи простых многоклеточных эндоэпителиальных желез. Таким образом, при обеспечении достаточной циркуляции воздушных потоков в закрытом помещении толщина слизистой оболочки и собственной пластинки уменьшается, а толщина эпителиального слоя и высота ресничек трахеи увеличиваются. Эти показатели состояния птицы могут служить индикаторами благоприятных условий содержания.

Ключевые слова: Gallus gallus, гистоструктура трахеи, слизистая трахеи, реснитчатый эпителий, микроклимат, циркуляция воздушных потоков, респираторная система, гистохимия, ШИК-реакция, альциановый синий.

Морфофункциональное строение дыхательной системы млекопитающих широко изучено, в частности исследованы морфогенез мерцательного и реснитчатого эпителия (1-3), механизмы мукоцилиарного аппарата $(4,5)$, в то время как особенностям анатомического строения респираторных

\footnotetext{
* Статья подготовлена при финансовой поддержке РГАУ-МСХА имени К.А. Тимирязева. Тема проекта: «Гистоструктура органов дыхательной системы сельскохозяйственных птиц в зависимости от особенностей микроклимата в птичниках» (проект № 1.2.10). 
органов птиц уделено значительно меньше внимания $(6,7)$. Исследовано гистологическое строение дыхательных путей разных видов птиц $(8,9)$, в том числе морфология трахеи и гортани перепелов (10), бройлеров (11), индеек $(12)$ и цесарок $(13,14)$, а также легких и воздухоносных мешков гусей, индеек, кур, уток (15).

Функции респираторной системы птиц заключаются в газообмене и поддержании в организме температурного гомеостаза. Трахея проводит воздух из гортани к легким, при этом воздух увлажняется, согревается и очищается от механических частиц, бактерий и вирусов. У птиц (как и у млекопитающих) трахея состоит из слизистой оболочки, подслизистой основы, фиброзно-хрящевой оболочки и адвентиции $(9,16)$. Слизистая оболочка выстлана многорядным мерцательным эпителием, в составе которого есть несколько видов клеток. Основная масса - это высокие реснитчатые клетки, доходящие до края пласта и несущие на апикальном полюсе реснички. Также среди клеток эпителия встречаются бокаловидные клетки простые одноклеточные железы, выделяющие слизистый секрет (1).

Соотношение разных типов клеток зависит от вида животного, возраста, состояния здоровья и внешних условий. О.А. Матвеев с соавт. (11) при исследовании трахеи цыплят-бройлеров кросса Ross 308 определили соотношение бокаловидных к остальным клеткам эпителия как 1:10. Под эпителием располагается собственная пластинка слизистой, которая сформирована рыхлой соединительной тканью. В ней залегают коллагеновые, эластические и ретикулярные волокна, между которыми находится основное аморфное вещество (12). Далее расположена подслизистая основа, тоже образованная рыхлой соединительной тканью. Некоторые авторы описывают собственную пластинку и подслизистую основу как плотную соединительную ткань (9). За ней следует фиброзно-хрящевая оболочка, состоящая из гиалиновых колец, между которыми находится плотная соединительная ткань. У птиц хрящи трахеи замкнутые, заходят друг за друга и у некоторых видов могут окостеневать $(12,16)$. Слизь, выделяемая бокаловидными клетками и трахеальными железами, вязкая, содержит ШИК-положительные гликопротеиды и гликозаминокликаны, которые окрашиваются альциановым синим (1). Гликозаминогликаны представляют собой высокосульфатированные полисахариды, образующие с молекулами белка протеогликаны (17). Эта слизь находится поверх ресничек, и к ней прилипают механические частички и бактерии, попадающие с вдыхаемым воздухом. Деятельность реснитчатого аппарата, бокаловидных клеток и трахеальных желез отличается синхронностью и формирует мукоцилиарную систему транспорта в трахее и бронхах, тем самым создавая защитный механизм. Нарушения в этой системе приводят к воспалительной реакции (1).

Выполняя защитные функции, трахея в первую очередь оказывается подвержена повреждению и изменению гистологической структуры под влиянием окружающей среды. Так, отмечена способность мерцательного эпителия при агрессивных внешних воздействиях (пары ядовитых веществ, механические и термические воздействия) преобразовываться в типичный многослойный эпителий (1). В литературе описано угнетающее действие радиоактивного излучения на все элементы стенки трахеи (7) и отрицательное влияние углекислого газа, приводящее к отекам слизистой (2). В ряде работ отмечено влияние низких температур на анатомо-гистологическое строение трахеи $(4,18,19)$.

В большинстве случаев возникновению неинфекционных респираторных заболеваний бройлеров способствует несоответствие условий со- 
держания физиологическим нормам развития птицы (20). Аллергические реакции респираторной системы птиц происходят не только из-за наличия патогенной микрофлоры в воздушно-пылевом биоаэрозоле $(21,22)$, но и вследствие недостаточной циркуляции воздуха в закрытых производственных помещениях $(23,24)$.

В настоящее время проведено достаточно исследований гистологической структуры дыхательной системы у сельскохозяйственных птиц в зависимости от резистентности особей к респираторным заболеваниям (25), заражения инфекционным бронхитом кур $(26,27)$ и вирусом ларинготрахеита $(28,29)$, контаминации воздуха $(20)$, равномерности микроклимата $(30$, $31)$, концентрации вредных газов $(32,33)$, однако не изучена гистологическая и гистохимическая структура трахеальной стенки птиц, выращиваемых в закрытых помещениях с разной циркуляцией воздуха.

В представленной работе впервые показано, что циркуляция воздуха в закрытых помещениях способствует поддержанию продуктивности, улучшению гистологической структуры и гистохимического статуса трахеальной стенки цыплят-бройлеров.

Цель эксперимента - определение гистологической и гистохимической структуры трахеальной стенки, а также динамики живой массы у цыплят-бройлеров (Gallus gallus domesticus) кросca Ross 308, содержащихся в вентилируемых помещениях и при отсутствии циркуляции воздуха.

Методика. Работу выполняли в 2020-2021 годах на птицефабрике ООО «Челны-Бройлер» (Республика Татарстан), благополучной по эпизоотическому состоянию. Цыплят-бройлеров кросcа Ross 308 выращивали до 39-суточного возраста в пяти закрытых производственных корпусах, которые различались по равномерности распределения воздушных потоков и циркуляции воздуха (пять групп по 35 гол. в каждой, отобраны методом пар-аналогов). Птицу содержали на глубокой подстилке. Кормление полнорационными комбикормами было семифазовым. На 3-ю, 4-ю и 5-ю нед оценивали живую массу индивидуальным взвешиванием.

Трахеи получали от всех 35 бройлеров (средняя живая масса 2500 г) в каждой из пяти групп (всего 175 образцов). Образцы фиксировали в $10 \%$ формалине, затем промывали водой и заливали в парафин. Срезы тканей толщиной 5 мкм (по три среза каждого образца, всего 525 препаратов) готовили по стандартным методикам (17) и окрашивали гематоксилином и эозином для приготовления обзорных препаратов. Для гистохимических исследований кислых и нейтральных муцинов срезы окрашивали комбинированным методом выявления полисахаридов с применением реакции Шиффйодной кислоты (ШИК-реакции) и альцианового синего (кислые гликозаминогликаны окрашиваются в синий цвет, ШИК-положительные гликопротеины - в фиолетовый) (17). Для более точного дифференцирования гликопротеинов от протеогликанов, содержащих в своем составе кислые гликозаминогликаны, срезы, полученные с тех же образцов, окрашивали при помощи только ШИК-реакции. Использовали наборы реактивов фирмы «ООО Лабико» (Россия) в соответствии с методикой, рекомендованной производителем.

Препараты просматривали под световым биологическим микроскопом Биолам М-3 (АО «ЛОМО», Россия) с разными кратностями увеличения $(15 \times 8,15 \times 20$ и $15 \times 40)$, фотографировали и описывали. Оценку толщины эпителия и подсчет ресничек трахеи проводили с помощью окуляр-микрометра с последующим переводом относительных значений в абсолютные на объект-микрометре. 
Во всех помещениях, где содержалась птица, воздухообмен обеспечивался приточно-вытяжной системой вентиляции, работающей по принципу отрицательного давления. Циркуляционные осевые вентиляторы SF550-02 («AgroKurs», Россия) производительностью 8,5 тыс. м³/ч каждый (суммарная производительность 42,5 тыс. м³/ч) в залах № 1 (I группа) и № 5 (V группа) были установлены на одной высоте с газогенераторами, на расстоянии 10,8 м от выходных отверстий газогенераторов, под наклоном $5^{\circ}$ вниз по направлению к птице. Электропитание циркуляционных вентиляторов осуществлялось совместно с газогенераторами, включение обогрева и циркуляции воздуха в помещениях происходило одновременно. В зале № 1 движение воздушных потоков от циркуляционных вентиляторов было направлено к вытяжной вентиляции, в зале № 5 - от вытяжной вентиляции. Циркуляционные вентиляторы запускали с 10-суточного возраста бройлеров. В помещениях, где содержались II, III и IV контрольные группы, циркуляционные вентиляторы отсутствовали. Контрольные группы различались между собой возрастом родительского стада птицы, от которой были отведены цыплята-бройлеры для выращивания: II группа - 28 нед, III группа -47 нед, IV группа - 38 нед.

При проведении эксперимента соблюдали требования рекомендаций «Guide for the Care and Use of Agricultural Animals in Research and Teaching, 3d edition» (Federation of Animal Science Societies, 2010). Были предприняты все меры, чтобы свести к минимуму страдания птиц и уменьшить число особей, подвергнутых эвтаназии.

Статистическую обработку проводили методом вариационной статистики с использованием $t$-критерия Стьюдента в пакете Microsoft Excel 2010. Рассчитывали средние значения $(M)$ и стандартные ошибки средних ( \pm SEM). Различия считали статистически значимыми при $\mathrm{p} \leq 0,01$ для биологических значений, $\mathrm{p} \leq 0,05$ - для зоотехнических значений.

Pезультаты. У цыплят кросса Ross 308 морфогенез трахеи заканчивается к 35-м сут постнатального онтогенеза (11), поэтому все изменения в гистологическом строении, наблюдаемые нами, не были возрастными. Образцы тканей у птицы из I и V групп отличались от образцов из II, III и IV групп меньшей толщиной слизистой оболочки и собственной пластинки.

1. Толщина слоев (мкм) слизистой оболочки трахеи у цыплят-бройлеров (Gallus gallus domesticus) кросса Ross 308 в зависимости от циркулящии воздуха в помещении ( $M \pm \mathrm{SEM}$, условия птичника, ООО «Челны-Бройлер», Республика Татарстан, 2020-2021 годы)

\begin{tabular}{|c|c|c|c|c|c|}
\hline \multirow{2}{*}{ Стенка трахеи } & \multicolumn{5}{|c|}{ Группа $(n=105)$} \\
\hline & I & II & III & IV & $\mathrm{V}$ \\
\hline Слизистая оболочка & $147,2 \pm 3,3$ & $267,5 \pm 4,1^{*}$ & $404,7 \pm 9,4^{*}$ & $298,1 \pm 10,5^{*}$ & $161,2 \pm 2,9^{*}$ \\
\hline Собственная пластинк & & & & & \\
\hline слизистой & $129,1 \pm 3,1$ & $253,9 \pm 4,2^{*}$ & $395,7 \pm 9,4^{*}$ & $285,3 \pm 10,4^{*}$ & $144,8 \pm 2,9 *$ \\
\hline Эпителиальный слой & $16,1 \pm 0,4$ & $16,2 \pm 0,3$ & $13,2 \pm 0,3^{*}$ & $15,1 \pm 0,3^{*}$ & $18,4 \pm 0,4 *$ \\
\hline Реснички & $4,3 \pm 0,1$ & $2,6 \pm 0,1^{*}$ & $1,8 \pm 0,1^{*}$ & $1,4 \pm 0,1^{*}$ & $4,3 \pm 0,1^{*}$ \\
\hline
\end{tabular}

У птицы из I опытной группы толщина слизистой оболочки и входящей в ее состав собственной пластинки оказалась минимальной (соответ-

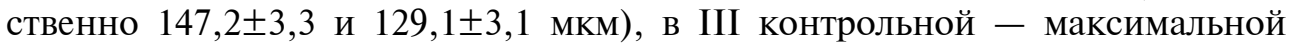
$(404,7 \pm 9,4$ мкм и $395,7 \pm 9,4$ мкм) (p $\leq 0,01)$. Толщина эпителиального слоя трахеи была достоверно выше в I и V опытных группах в среднем на $14 \%$ в сравнении со II, III и IV контрольными группами (p $\leq 0,01)$. Отсутствие циркуляции воздуха в помещениях привело к статистически значимому снижению высоты ресничек во II, III и IV группах соответственно на 39,5; 
58,1 и 67,5 \% по отношению к I и V опытным группам (p $\leq 0,01)$ (табл. 1).

С увеличением толщины эпителия и высоты ресничек возрастает способность удерживания в слизистой частиц вдыхаемого воздуха. Реснички как органеллы движения играют решающую роль в защите дыхательных путей от экзогенных частиц и участвуют в реакциях неспецифического иммунитета (1). Статистически значимое увеличение размера ресничек в группах с циркуляцией воздуха указывало на лучшие условия для выращивания птицы. Тенденция увеличения размера ресничек в зависимости от толщины эпителия отсутствовала.

Микрофотографии гистоструктуры трахеальной стенки птиц приведены для групп I, V и III, исходя из минимальных и максимальных значений показателей.

Гистологические исследования подтвердили существующие данные о том, что стенка трахеи птиц состоит из слизистой, подслизистой, фиброзно-хрящевой оболочек и адвентиции $(9,16,34)$. Слизистая, в свою очередь, включала многорядный мерцательный эпителий и собственную пластинку слизистой оболочки, представленную рыхлой соединительной тканью. Кроме волокнистого компонента и основного аморфного вещества, в ней встречались клеточные формы, характерные для этого вида ткани, и клетки крови лейкоцитарного ряда. Подслизистая оболочка состояла из рыхлой соединительной ткани с преобладанием волокнистого компонента, что также согласуется с данными, полученными ранее (9, 11-13). Фибрознохрящевая оболочка была представлена замкнутыми кольцами гиалинового хряща и плотной соединительной тканью между ними. Из-за того, что анатомически кольца трахеи перекрывали друг друга, на препарате можно было увидеть одновременно срез двух соседних колец. Адвентиция была представлена рыхлой соединительной тканью (рис. 1).
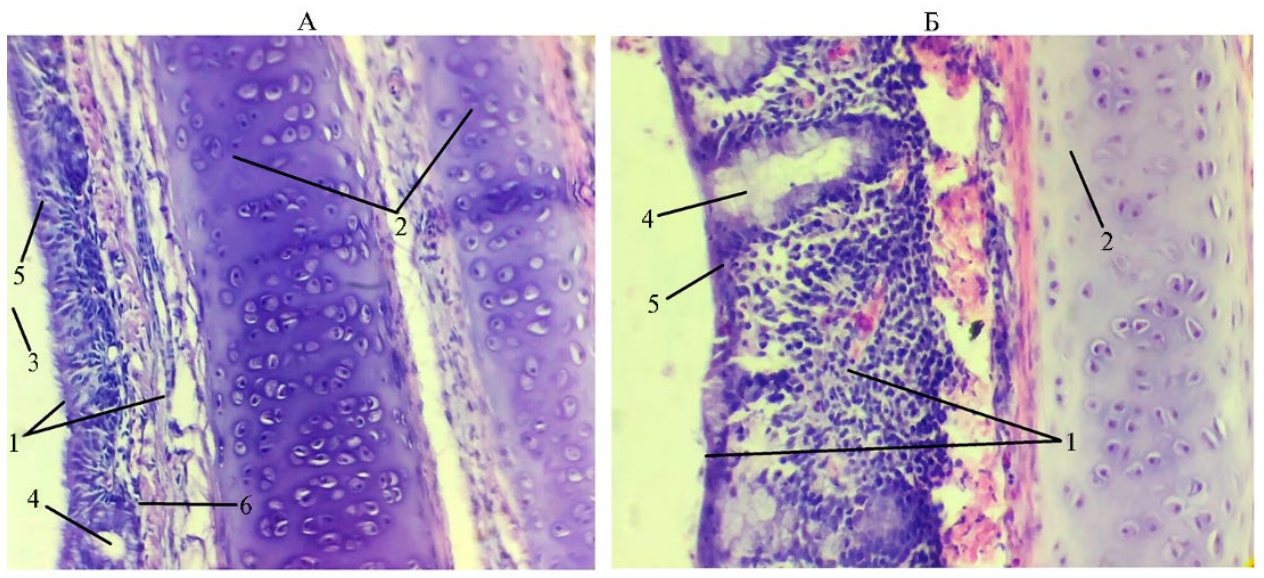

Рис. 1. Гистологическая структура стенки трахеи у цыплят-бройлеров (Gallus gallus domesticus) кросса Ross 308 из I групп, которую содержали в вентилируемом помещении (A), и III группы, находившейся в помещении без циркуляции воздуха (Б): 1 - слизистая оболочка, 2 - фибрознохрящевая оболочка, 3 - просвет трахеи, 4 - слизистые железы, 5 -эпителий, 6 - собственная пластинка слизистой (условия птичника, ООО «Челны-Бройлер», Республика Татарстан, 20202021 годы). Окрашивание гематоксилином и эозином, увеличение $15 \times 20$, микроскоп Биолам М-3 (АО «ЛОМО», Россия).

Комплексное проведение ШИК-реакции и окрашивание срезов альциановым синим позволило проследить распределение кислых гликозаминогликанов и ШИК-положительных гликопротеинов в структурах стенки органа (рис. 2).

Дополнительное проведение ШИК-реакции подтвердило локализа- 
цию нейтральных мукополисахаридов, поскольку в некоторых случаях они перекрывались более ярким окрашиванием альциановым синим. Так, кислые мукополисахариды, содержащие сульфатированные гликозаминогликаны и окрашенные на препарате в ярко-синий цвет, в основном локализовались в хряще и входили в состав слизи, выделяемой как одноклеточными, так и многоклеточными железами. Дополнительная идентификация ШИК-реакцией выявила, что нейтральные гликопротеины, окрашиваемые в фиолетовый цвет, обнаруживаются в секрете желез в максимальной концентрации и значительно слабее окрашены в области хряща. В фиброзно-хрящевой оболочке они в основном локализовались в области надхрящницы и в зоне молодого хряща. Наблюдаемое распределение химических групп указывает на то, что хондромукоид был в большей степени представлен сульфатированными (кислыми) мукополисахаридами, чем нейтральными. Слизь, выделяемая железами, состояла в равной мере из кислых и нейтральных мукополисахаридов. Распределение этих групп веществ по другим структурам стенки органа показало, что как кислые гликозаминогликаны, так и нейтральные гликопротеины в умеренных количествах обнаруживались в межклеточном веществе рыхлой соединительной ткани.
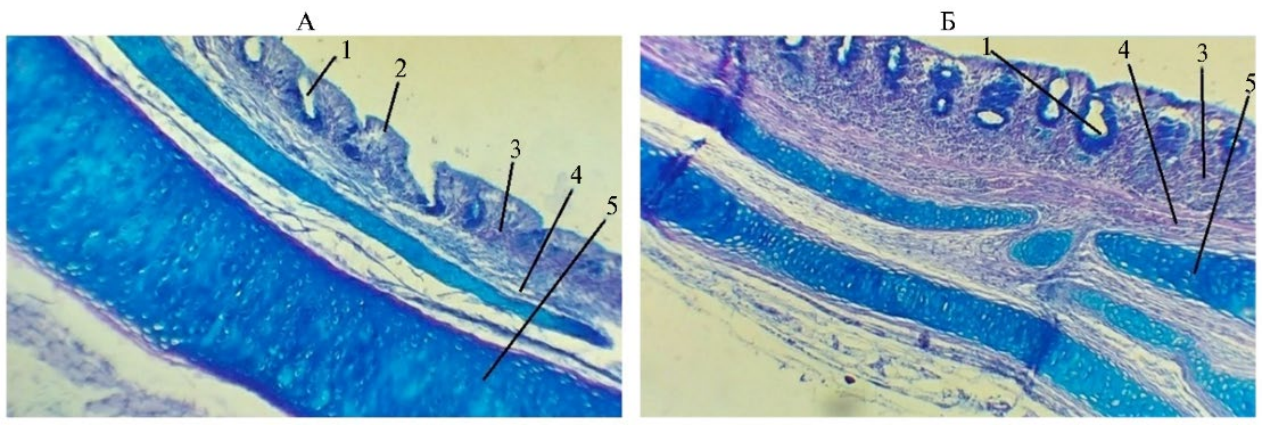

Рис. 2. Гистологическая структура стенки трахеи у цыплят-бройлеров (Gallus gallus domesticus) кросса Ross 308 из V группы, которую содержали в вентилируемом помещении (A), и III группы, находившейся в помещении без циркуляции воздуха (Б): 1 - железы, 2 - эпителий, 3 - собственная пластинка слизистой, 4 - подслизистая оболочка, 5 - фиброзно-хрящевая оболочка (условия птичника, ООО «Челны-Бройлер», Республика Татарстан, 2020-2021 годы). Окрашивание альциановым синим + ШИК-реакция, увеличение $15 \times 8$, микроскоп Биолам М-3 (АО «ЛОМО», Россия).

В трахее у птиц из V группы патологические изменения в реснитчатом эпителии отсутствовали. В собственной пластинке слизистой оболочки были видны ядра фиброцитов, волокнистый компонент и основной аморфный компонент. В однослойном многорядном мерцательном эпителии мы обнаружили высокие цилиндрические клетки с ресничками на апикальном полюсе и камбиальные клетки, не доходящие до края пласта и расположенные около базальной мембраны. Апикальный полюс клеток не был разрушен (см. рис. 1). Местами в пласте эпителия присутствовали бокаловидные клетки, выделяющие слизь. Кроме бокаловидных клеток в пласте эпителия мы обнаружили простые эндоэпителиальные железы (рис. 3), что отмечалось $(9,12,13)$. Их содержимое имело одновременно ШИК-положительную реакцию и окрашивалось альциановым синим. Бокаловидные клетки встречались как поодиночке, так и небольшими группами в несколько клеток, лежащих рядом (рис. 4), что подтверждают некоторые исследования $(4,12)$.

Кроме того, в собственной пластинке располагались простые трахеальные слизистые железы, имеющие такую же окраску. Зона ресничек более активно окрашивалась альциановым синим, в то время как слизь в железах одинаково хорошо окрашивалась и тем, и другим методами. Вероятно, 
слизь, находящаяся около ресничек и составляющая более жидкую фракцию (4), содержала больше кислых мукополисахаридов. В соединительной ткани слизистой и подслизистой оболочки преобладали кислые мукополисахариды (см. рис. 2). При изучении гистоструктуры трахеи птицы из I группы результаты были схожие с полученными для V группы.


B


Рис. 3. Гистологическая структура стенки трахеи у цыплят-бройлеров (Gallus gallus domesticus) кросса Ross 308 из V группы, которую содержали в вентилируемом помещении (А, Б), и III группы, находившейся в помещении без циркуляции воздуха (В, Г): 1 - железы, 2 - эпителий, 3 - хрящ, 4 - реснички, 5 - собственная пластинка слизистой (условия птичника, ООО «Челны-Бройлер», Республика Татарстан, 2020-2021 годы). Слева - ШИК-реакция, справа окрашивание альциановым синим + ШИК-реакция, увеличение $15 \times 40$, микроскоп Биолам М-3 (АО «ЛОМО», Россия).

В трахее у птиц из III группы отмечали заметное уменьшение толщины эпителия (см. рис. 1). Местами эпителий подвергается метаплазии, в остальных участках его высота была достоверно ниже $(\mathrm{p} \leq 0,01)$ в сравнении с I и V группами, кое-где реснички практически отсутствовали. В просвете трахеи иногда встречались группы клеток или отдельно лежащие клетки, среди которых присутствовали эритроциты, макрофаги и лейкоциты, мигрировавшие из собственной пластинки слизистой на поверхность эпителия. Это согласуется с данными о застойных явлениях в дыхательной системе птиц в связи с недостаточной циркуляцией воздуха (4). Частичный недостаток воздухообмена приводит к сверхнормативной концентрации вредных газов и повышенной запыленности, что может вызывать воспалительный процесс в трахеальной стенке. Подобный эффект был получен в эксперименте по выращиванию бройлеров с 42-суточного возраста в птичнике с концентрацией 100 ppm NH3/л воздуха в течение 1 нед (32) и в опыте по содержанию индеек в птичнике с концентрацией 10 ppm NH3/л воздуха 
(33). В этих работах не обнаружено повреждений реснитчатого эпителия и бокаловидных клеток в трахее птиц, однако трахея индеек имела угнетенное состояние мукоцилиарного аппарата, характеризующееся спутанными ресничками и участками децилирования $(32,33)$.

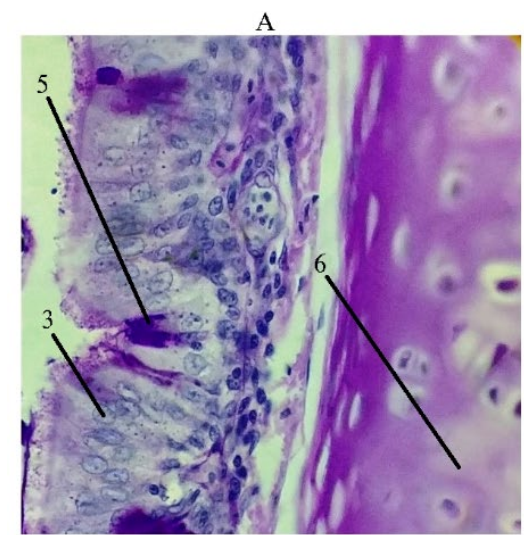

B

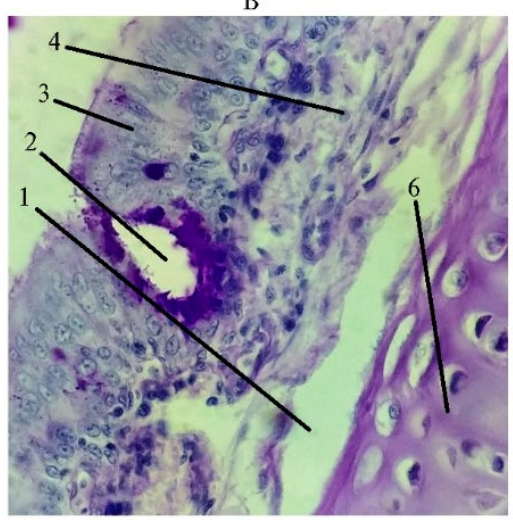

Б

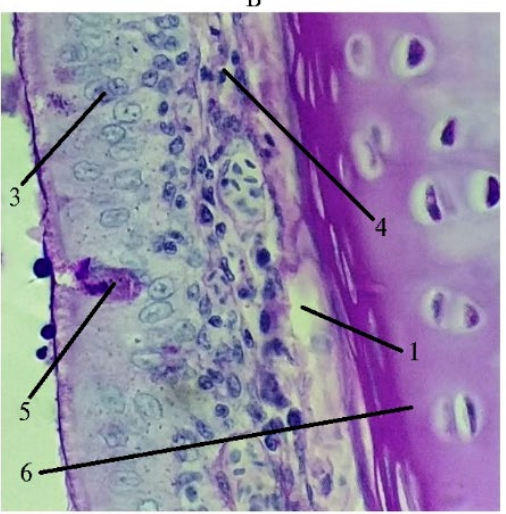

$\Gamma$

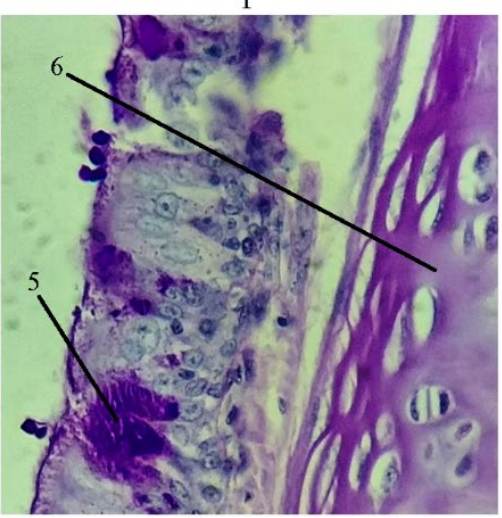

Рис. 4. Эндоэпителиальные железы и бокаловидные клетки в трахее у цыплят-бройлеров (Gallus gallus domesticus) кросса Ross 308 из V группы, которую содержали в вентилируемом помещении: 1 - подслизистая оболочка, 2 - эндоэпителиальные железы, 3 - эпителий, 4 - собственная пластинка слизистой, 5 - бокаловидные клетки, 6 - хрящ (условия птичника, ООО «ЧелныБройлер», Республика Татарстан, 2020-2021 годы). ШИК-реакция, увеличение 15×40, микроскоп Биолам М-3 (АО «ЛОМО», Россия).

Полученные в нашем опыте данные частично сопоставимы с описанием патологий, которые встречаются при инфицировании цыплят. Так, перестройка реснитчатого эпителия, катаральное воспаление и отек эпителия слизистой за счет инфильтрации лимфоцитами наблюдаются при инфицировании изолятом вируса гриппа птиц и ларинготрахеите $(28,29)$. Отмечена децилиация, десквамация и альтерация клеток реснитчатого эпителия трахеи при заражении вирусом инфекционного бронхита кур $(26,27,35)$.

При выявлении мукополисахаридов в III контрольной группе мы наблюдали активную ШИК-реакцию и окрашивание альциановым синим пласта эпителия, чего не было в I и V опытных группах. В собственной пластинке слизистой оболочки трахеи птиц из III группы преобладал клеточный компонент, волокна были малочисленны. Слизистая оказалась инфильтрирована лейкоцитами, среди которых преобладали лимфоциты. В рыхлой соединительной ткани слизистой и подслизистой у птиц из III (контрольной) группы выявляли больше гликопротеинов, чем в I и V опытных группах (см. рис. 2). Многорядность эпителия была слабо выражена, 
местами наблюдалась децилиация и метаплазия. У птиц из II и IV групп гистоструктура трахеи была схожа с наблюдаемой в образцах от цыплят из III группы.

К отеку слизистой может приводить повышенная концентрация углекислого газа во вдыхаемом воздухе, что подтверждается ранними исследованиями (2). Слои слизистой оболочки трахеи птиц, инфицированных штаммами вируса инфекционного бронхита кур разных серотипов, характеризуются умеренным отеком собственной пластинки слизистой оболочки и отслоением эпителиальных клеток трахеи, увеличением количества бокаловидных клеток $(26,27)$.

Считается, что бокаловидные клетки и трахеальные железы выделяют вязкую слизь под влиянием местных раздражающих факторов и не иннервируются адренергическими и холинергическими рецепторами (35). Кроме того, бокаловидные клетки имеют короткий период жизни, всего 24 сут (1), поэтому могут быть чувствительными к внешним воздействиям. Следовательно, различные местные воздействия на слизистую приводят к количественным и качественным изменениям в этих железах.

Мы показали, что в начальном участке трахеи у птиц из I и V опытных групп присутствовали и трахеальные железы, и бокаловидные клетки, но наблюдался сдвиг баланса в сторону желез. Эти результаты согласуются с ранее полученными данными $(9,12,13)$ о том, что железы преобладают в начальных участках, а бокаловидные клетки - в каудальной части трахеи. При этом бокаловидные клетки лежали как поодиночке, так и группами. Гистохимические методы окраски выявили клетки, заполненные слизистым секретом полностью, изредка встречались бокаловидные клетки с незначительным окрашиванием, предположительно генерализованно выделившие секрет гранул (см. рис. 4). Подобным образом описаны бокаловидные клетки у человека (1). Некоторые авторы отмечают увеличение количества бокаловидных клеток при воздействии неблагоприятных факторов среды на эпителий трахеи $(4,7,26,27)$.

В наших исследованиях во II, III и IV контрольных группах при недостаточной вентиляции мы обнаружили уменьшение количества бокаловидных клеток, что, по-видимому, было связано со структурными изменениями в эпителии, однако наблюдалось увеличение количества трахеальных желез. Это подтверждалось повышенным количеством ШИК-положительных мукополисахаридов в рыхлой соединительной ткани вокруг желез. Следует отметить ярко выраженное увеличение содержания кислых и нейтральных мукополисахаридов в контрольных группах по сравнению с опытными. Такие гистохимические и морфологические изменения в стенке трахеи у птицы, которую содержали в условиях недостаточной вентиляции, видимо, служат компенсаторным механизмом восстановления мукоцилиарного транспорта.

2. Динамика живой массы (г) у цыплят-бройлеров (Gallus gallus domesticus) кросca Ross 308 в зависимости от циркуляции воздуха в помещении ( $M \pm \mathrm{SEM}$; условия птичника, ООО «Челны-Бройлер», Республика Татарстан, 20202021 годы)

\begin{tabular}{|c|c|c|c|}
\hline Группа $(n=35)$ & 3-я нед & 4-я нед & 5-я нед \\
\hline I опытная & $1047,6 \pm 10,6$ & $1712,2 \pm 12,4$ & $2366,9 \pm 19,2$ \\
\hline II контрольная & $1080,9 \pm 10,2$ & $1602,0 \pm 19,2^{*}$ & $2214,1 \pm 29,1^{*}$ \\
\hline III контрольная & $1149,3 \pm 11,7$ & $1688,2 \pm 15,5$ & $2290,7 \pm 18,5^{*}$ \\
\hline IV контрольная & $1110,4 \pm 10,3$ & $1591,1 \pm 10,4^{*}$ & $2198,2 \pm 21,0^{*}$ \\
\hline V опытная & $1159,6 \pm 11,2$ & $1690,1 \pm 16,5$ & $2317,6 \pm 20,0$ \\
\hline
\end{tabular}


Мы изучили изменение прироста живой массы у цыплят-бройлеров на фоне разной циркуляции воздуха (табл. 2). Прирост живой массы птицы в 5-недельном возрасте в I опытной группе был выше в сравнении co II, III и IV контрольными группами соответственно на 6,5; 3,2 и 7,1 \% $(\mathrm{p} \leq 0,05)$. В 4-недельном возрасте в I опытной группе различия по отношению ко II и IV контрольным группам составили 6,4 и 7,1 \% (p $\leq 0,05)$, в то время как до 4-недельного возраста статистически значимые различия отсутствовали.

Таким образом, мы подтвердили зависимость состояния гистоструктуры и гистохимического статуса трахеальной стенки у цыплят-бройлеров кросca Ross 308 от циркуляции воздуха в производственных помещениях закрытого типа. Недостаточность циркуляции воздушных потоков в залах выращивания птиц вызывает деструктивные изменения слизистой оболочки трахеи, которые выражаются в разрастании собственной пластинки слизистой, отеке, уменьшении высоты эпителия, разрушении ресничек, снижении продуктивности. Это приводит к метаплазии эпителия и нарушению мукоцилиарного транспорта. С обеспечением циркуляции воздушных потоков в закрытых помещениях толщина слизистой оболочки уменьшается, а высота эпителиального слоя и ресничек трахеи увеличивается. О благоприятном влиянии циркуляции воздуха в закрытых помещениях для выращивания птиц достоверно свидетельствует истончение слизистой оболочки трахеи в 2,6 раза (на 61,9\%), уменьшение толщины собственной пластинки в 2,9 раза (на 65,4 \%), увеличение толщины эпителиального слоя в 1,3 раза (на 23,3 \%) и высоты ресничек в 3,1 раза (на 67,5 \%), а также увеличение прироста живой массы птицы (до 7,1 \%). Полученные гистологические препараты позволяют предположить наличие у птиц в пласте эпителия трахеи простых многоклеточных эндоэпителиальных желез. Описанные изменения гистоструктуры трахеальной стенки могут служить индикаторами неблагоприятных условий содержания птицы. Выращивание мясных кроссов непродолжительно, поэтому для изучения последствий более длительного воздействия высокой загазованности и запыленности воздуха следует использовать другие технологические группы птицы (например, родительское стадо).

\footnotetext{
1 ФНЦ Всероссийский научно-исследовательский и технологический институт птицеводства РАН, 141311 Россия, Московская обл., г. Сергиев Посад, ул. Птицеградская, 10, e-mail: fisinin@land.ru, saleeva@vnitip.ru;

2Институт зоотехнии и биологии

РГАУ-МСХА им. К.А. Тимирязева,

127550 Россия, г. Москва, ул. Тимирязевская, 49,

e-mail: ptitsa@rgau-msha.ru,panovvp@rgau-msha.ru, malorodov56@gmail.com $\bowtie$, ncherepanova@rambler.ru;

3000 «Челны-Бройлер»,

423800 Россия, Республика Татарстан, г. Набережные Челны,

ул. Стройбаза, 8 ,

e-mail: hamitova-valeriy@mail.ru
}

Sel'skokhozyaistvennaya biologiya [Agricultural Biology], 2021, V. 56, № 4, pp. 782-794

Поступила в редакцию 25 мая 2021 года

\title{
HISTOSTRUCTURE OF THE TRACHEAL WALL OF BROILER CHICKENS DEPENDING ON AIR CIRCULATION CONDITIONS IN CLOSED POULTRY HOUSES
}

\author{
V.I. Fisinin 1 , I.P. Saleeva ${ }^{1}$, A.K. Osmanyan ${ }^{2}$, V.P. Panov', V.V. Malorodov ${ }^{2}$,
}




\section{N.G. Cherepanova², V.Z. Hamitova ${ }^{3}$}

${ }^{1}$ Federal Scientific Center All-Russian Research and Technological Poultry Institute RAS, 10, ul. Ptitsegradskaya, Sergiev Posad, Moscow Province, 141311 Russia, e-mail fisinin@land.ru, saleeva@vnitip.ru;

${ }_{2}^{2}$ Department of Zootechny and Biology, Russian State Agrarian University - Timiryazev Moscow Agricultural Academy, 49, ul. Timiryazevskaya, Moscow, 127550 Russia, e-mail ptitsa@rgau-msha.ru, panovvp@rgau-msha.ru, malorodov56@gmail.com ( $\square$ corresponding author),ncherepanova@rambler.ru;

${ }^{3}$ Ltd «Chelny-Broiler», 8, ul. Stroybaza, Naberezhnye Chelny, Republic of Tatarstan, 423800 Russia, e-mail hamitova-valeriy@mail.ru

ORCID:

Fisinin V.I. orcid.org/0000-0003-0081-6336

Saleeva I.P. orcid.org/0000-0002-7446-1593

Malorodov V.V. orcid.org/0000-0001-9033-7552

Osmanyan A.K. orcid.org/0000-0002-0677-4264

Cherepanova N.G. orcid.org/0000-0001-7484-9021

Panov V.P. orcid.org/0000-0002-7075-580X

The authors declare no conflict of interests

Acknowledgements:

Supported financially from the Russian State Agrarian University - Timiryazev Moscow Agricultural Academy (project No. 1.2.10)

Received May 25, 2021

doi: 10.15389/agrobiology.2021.4.782eng

\section{Abstract}

Currently, optimization of indoor microclimatic conditions in poultry houses is attracting considerable interest due to the intensification of broiler meat production. However, given the increase in flock sizes of broilers, little research has focused on the effect of microclimate parameters in poultry houses on the bird's respiratory system. Insufficient air exchange in the premises can cause functional respiratory disorders in broiler chickens. This paper is the first to report that air circulation in closed poultry houses contributes to maintaining productivity and improves the histostructure and histochemical properties of the tracheal wall in broiler chicks (Gallus gallus domesticus). Our work aimed to study the influence of different air circulation regimes in closed poultry houses on histostructure and histochemical characteristic of the trachea in Ross 308 broiler chicks and their productive performance. The study was conducted in 2020-2021 at the LLC Chelny-Broiler poultry farm (Republic of Tatarstan). Ross 308 cross broiler chicks were raised until 39 days of age in five closed premises under different airflow distribution and air circulation (five groups of 35 birds each). For morphometry, 525 preparations of 175 trachea specimens from of all broilers ( $2500 \mathrm{~g}$ bodyweight) were measured. Trachea sections were stained by hematoxylin and eosin procedure. For histochemical studies of acidic and neutral mucins, sections were stained by a combined method for detecting polysaccharides using the Schiff-iodic acid (PAS-reaction) and alcian blue according to the manufacturer's recommended (LLC Labico, Russia). In the control groups 2, 3, and 4, there was no air circulation; in the experimental groups I and V, circulation was provided by forced ventilation, capacity of 8.5 thousand $\mathrm{m}^{3} / \mathrm{h}$ (SF550-02, AgroKurs, Russia). Ventilation was run at the 10 day-age of the broiler chicks. Insufficient air circulation in the poultry rearing rooms caused destructive changes in the tracheal mucous membrane, i.e., its own lamina proliferation, edema, a decrease in the height of the epithelium, and destruction of cilia. This led to metaplasia of the epithelium and disruption of mucociliary transport. The thickness of the mucous membrane and its own lamina was minimum in the experimental group $1(147.2 \pm 3.3$ $\mu \mathrm{m}$ and $129.1 \pm 3.1 \mu \mathrm{m}$, respectively) and maximum in the control group $3(404.7 \pm 9.4 \mu \mathrm{m}$ and $395.7 \pm 9.4 \mu \mathrm{m})(\mathrm{p} \leq 0.01)$. The thickness of the tracheal epithelial layer significantly increased in the experimental groups 1 and 5 (by $14 \%$ on average) compared to the control groups 1,2 , and 3 (p $\leq$ 0.01). The lack of indoor air circulation led to a significant decrease in the height of cilia in the control groups 2,3 , and 4 (by 39.5, 58.1, and 67.5\%, respectively) as compared to the experimental groups 1 and 5. The increase in birds' bodyweight at 5 weeks of age in the experimental group 1 increased compared to the control groups 2,3 , and 4 by $6.5,3.2$, and $7.1 \%$, respectively ( $\mathrm{p} \leq 0.05$ ). The histochemical characteristics suggests the presence of simple multicellular endoepithelial glands in the tracheal epithelium layer of birds. Thus, with the provision of proper air circulation in an enclosed space, the thickness of the mucous membrane and its own lamina decreases, and the thickness of the epithelial layer and the height of the tracheal cilia increases. These characteristics are indicative of proper airexchange in the poultry houses.

Keywords: Gallus gallus, trachea, histostructure, tracheal mucosa, ciliated epithelium, microclimate, air circulation, ventilation system, respiratory tract, histochemistry, PAS-reaction, alcian blue.

\section{REFEREN CES}

1. Zavalii M.A. Rinologiya, 2014, 1: 38-49 (in Russ.).

2. Belyaeva E.V., Rybakova A.V., Gushchin Ya.A., Vaganova D.S., Koptyaeva K.E., Muzhikyan A.A., Makarova M.N., Makarov V.G. Laboratornye zhivotnye dlya nauchnykh issledovanii, 2018, 3: 49-60 (doi: 10.29296/2618723X-2018-03-05) (in Russ.). 
3. Pavlov A.V., Esev L.I. Zhurnal anatomii i gistopatologii, 2017, 6(2): 62-67 (in Russ.).

4. Tseluiko S.S., Semenov D.A., Gorbunov M.M., Vislobokov N.A., Kazanskii P.R., SHvyndina N.V., Shklover V.Ya. Byulleten' fiziologii i patologii dykhaniya, 2012, 45: 52-56 (in Russ.).

5. Ross S.M., Corrsin S. Results of an analytical model of mucociliary pumping. Journal of Applied Physiology, 1974, 37(3): 333-340 (doi: 10.1152/jappl.1974.37.3.333).

6. Carvalho O., Gonçalves C. Comparative physiology of the respiratory system in the animal kingdom. The Open Biology Journal, 2011, 4: 35-46 (doi: 10.2174/1874196701104010035).

7. Troyanchuk O.V., Levchuk O.K. Uchenye zapiski uchrezhdeniya obrazovaniya Vitebskaya ordena Znak pocheta gosudarstvennaya akademiya veterinarnoi meditsiny, 2013, 49(1-1): 73-78 (in Russ.).

8. Maina J.N. Development, structure, and function of a novel respiratory organ, the lung-air sac system of birds: to go where no other vertebrate has gone. Biological Reviews Cambridge Philosophical Society, 2006, 81(4): 545-579 (doi: 10.1017/S1464793106007111).

9. Bacha J.W., Bacha M.L. Color atlas of veterinary histology, $3^{\text {rd }}$ edition. Lippincott Williams and Willcons Company, USA, 2012.

10. ÇEvik-Demirkan A., Haziroğlu R.M., Kürtül i. Gross morphological and histological features of larynx, trachea and syrinx in Japanese quail. Anatomia, Histologia, Embryologia, 2007, 36(3): 215 219 (doi: 10.1111/j.1439-0264.2007.00758.x).

11. Matveev O.A., Guz'ko A.P., Baimukhambetov R.K. Izvestiya Orenburgskogo gosudarstvennogo agrarnogo universiteta, 2018, 6(74): 170-173 (in Russ.).

12. Al-Mussawi A.M., Al-Mehanna A.H., Al-Baghdady F.H. Histological study of the trachea in indigenous male turkey (Meleagris gallopava). Al-Qadisiyah Journal of Veterinary Medicine Sciences, 2012, 11(2): 47-53.

13. Waad S.K. Comparative histological study of trachea in guinea fowl and coot bird. Basrah Journal of Veterinary research, 2015, 14(2): 122-128.

14. Samuelson D.A. Text book of veterinary histology. Saunders Elsevier, 2007.

15. Pervenetskaya M.V., Fomenko L.V. Aktual'nye voprosy veterinarnoi biologii, 2014, 1(21): 10-12 (in Russ.).

16. Vrakin V.F., Sidorova M.V. Anatomiya i gistologiya domashnei ptitsy [Anatomy and histology of poultry]. Moscow, 1984 (in Russ.).

17. Mikroskopicheskaya tekhnika: Rukovodstvo /Pod redaktsiei D.S. Sarkisova, Yu.P. Perova [Microscopic technique: manual. D.S. Sarkisov, Yu.P. Perov (eds.)]. Moscow, 1996 (in Russ.).

18. Su Y., Wei H., Bi Y., Wang Y., Zhao P., Zhang R., Li X., Li J., Bao J. Pre-cold acclimation improves the immune function of trachea and resistance to cold stress in broilers. Journal of Cellular Physiology, 2019, 234(5): 7198-7212 (doi: 10.1002/jcp.27473).

19. Su Y., Li S., Xin H., Li J., Li X., Zhang R., Li J., Bao J. Proper cold stimulation starting at an earlier age can enhance immunity and improve adaptability to cold stress in broilers. Poultry Science, 2020, 99(1): 129-141 (doi: 10.3382/ps/pez570).

20. Fisinin V.I., Trukhachev V.I., Saleeva I.P., Morozov V.Yu., Zhuravchuk E.V., Kolesnikov R.O., Ivanov A.V. Microbiological risks related to the industrial poultry and animal production (review). Sel'skokhozyaistvennaya biologiya [Agricultural Biology], 2018, 53(6): 1120-1130 (doi: 10.15389/agrobiology.2018.6.1120eng).

21. Bakutis B., Monstviliene E., Januskeviciene G. Analyses of airborne contamination with bacteria, endotoxins and dust in livestock barns and poultry houses. Acta Vet. Brno, 2004, 73(2): 283-289 (doi: 10.2754/avb200473020283).

22. Plewa K., Lonc E. Analysis of airborne contamination with bacteria and moulds in poultry farming: a case study. Pol. J. Environ. Stud., 2011, 20(3): 725-731.

23. Radon K., Danuser B., Iversen M., Monso E., Weber C., Hartung J., Donham K., Palmgren U., Nowak D. Air contaminants in different European farming environments. Ann. Agric. Environ. Med., 2002, 9(1): 41-48.

24. Fisinin V.I., Kavtarashvili A.Sh. Heat stress in poultry. I. Danger, related physiological changes, and symptoms (review). Sel'skokhozyaistvennaya biologiya [Agricultural Biology], 2015, 50(2): 162171 (doi: 10.15389/agrobiology.2015.2.162eng).

25. Fedde M.R. Relationship of structure and function of the avian respiratory system to disease susceptibility. Poultry Science, 1998, 77(8): 1130-1138 (doi: 10.1093/ps/77.8.1130).

26. Nesterova L.Yu. Vestnik donskogo gosudarstvennogo agrarnogo universiteta, 2016, 2-1(20): 16-22 (in Russ.).

27. Hodgson T., Casais R., Dove B., Britton P., Cavanagh D. Recombinant infectious bronchitis coronavirus Baudette with the spike protein gene of the pathogenic M41 strain remains attenuated but induces protective immunity. Journal of Virology, 2004, 78(24): 13804-13811 (doi: 10.1128/JVI.78.24.13804-13811.2004).

28. Kirkpatrick N.C., Mahmoudian A., Colson C.A., Devlin J.M., Noormohammadi A.H. Relationship between mortality, clinical signs and tracheal pathology in infectious laryngotracheitis. Avian Pathology, 2006, 35(6): 449-453 (doi: 10.1080/03079450601028803).

29. Oldoni I., Rodríguez-Avila A., Riblet S.M., Zavala G., García M. Pathogenicity and growth characteristics of selected infectious laryngotracheitis virus strains from the United States. Avian 
Pathology, 2009, 38(1): 47-53 (doi: 10.1080/03079450802632031).

30. Osmanyan A.K., Malorodov V.V., Cherepanova N.G., Saleeva I.P. Ptitsevodstvo, 2020, 12: 42-46 (doi: 10.33845/0033-3239-2020-69-12-42-46) (in Russ.).

31. Osmanyan A.K., Malorodov V.V. Ptitsa i ptitseprodukty, 2021, 1: $13-16$ (doi: 10.30975/2073-49992020-23-1-13-16) (in Russ.).

32. Al-Mashhadani E.H., Beck M.M. Effect of atmospheric ammonia on the surface ultrastructure of the lung and trachea of broiler chicks. Poultry Science, 1985, 64(11): 2056-2061 (doi: 10.3382/ps.0642056).

33. Nagaraja K.V., Emery D.A., Jordan K.A., Newman J.A., Pomeroy B.S. Scanning electron microscopic studies of adverse effects of ammonia on tracheal tissues of turkeys. American Journal of Veterinary Research, 1983, 44(8): 1530-1536.

34. Hodges R.D. The histology of the fowl. CA Academic Press, London, 1974.

35. Naumann H.H. On the defense mechanisms of the respiratory mucosa towards infection. Acta Oto-Laryngologica, 1980, 89(3-4): 165-176 (doi: 10.3109/00016488009127124). 